\title{
Hop (Humulus lupulus L.) extract inhibits obesity in mice fed a high-fat diet over the long term
}

\author{
Maho Sumiyoshi ${ }^{1}$ and Yoshiyuki Kimura ${ }^{2 *}$ \\ ${ }^{1}$ Division of Functional Histology, Department of Functional Biomedicine, Ehime University Graduate School of Medicine, \\ Shitsukawa, Toon City, Ehime 791-0295, Japan \\ ${ }^{2}$ Division of Biochemical Pharmacology, Department of Basic Medical Research, Ehime University Graduate School of \\ Medicine, Shitsukawa, Toon City, Ehime 791-0295, Japan
}

(Submitted 17 June 2011 - Final revision received 30 November 2011 - Accepted 25 January 2012 - First published online 3 April 2012)

\begin{abstract}
Hops (Humulus lupulus L.) are traditionally used to add bitterness and flavour to beer. Although the isomerised hop extracts produced by the brewing process have been thought to ameliorate lipid and glucose metabolism, the influence of untreated hop extracts on high-fat (HF) diet-induced obesity is unclear. The present study examined the anti-obesity effects of a hop extract in male C57BL/6J mice fed a HF diet, or HF diet plus 2 or $5 \%$ hop extract for 20 weeks. The oral glucose tolerance test was performed at week 19. Furthermore, water excretion was evaluated in water-loaded Balb/c male mice. The effects of the extract on lipid accumulation and PPAR $\gamma$ expression in 3T3-L1 adipocytes were examined. The hop extract inhibited the increase in body and adipose tissue weight, adipose cell diameter and liver lipids induced by the HF diet. Furthermore, it improved glucose intolerance. The extract enhanced water excretion in water-loaded mice. Various fractions of the hop extract inhibited lipid accumulation and PPAR $\gamma$ expression in 3T3-L1 adipocytes. Hop extracts might be useful for preventing obesity and glucose intolerance caused by a HF diet.
\end{abstract}

Key words: Hops (Humulus lupulus L.): Anti-obesity effects: High-fat diet: Glucose tolerance: PPAR $\gamma$

Hops (Humulus lupulus L.; Cannabaceae) are traditionally used to add bitterness and flavour to beer. An extract of hops reportedly increased gastric juice volume in pylorusligated rats ${ }^{(1)}$, and had favourable effects on vasomotor symptoms and other menopausal discomforts in a prospective, randomised, double-blind, placebo-controlled clinical study $^{(2)}$. There are reports that the humulone in hops has antibacterial, anticollagenase, anti-oxidative ${ }^{(3)}$ and antiangiogenic $^{(4)}$ activities, and inhibited phorbol ester-induced carcinogenesis through the suppression of cyclo-oxygenase-2 expression in mouse skin ${ }^{(5-7)}$. Xanthohumol, a chalcone from beer hops, was reported to ameliorate lipid and glucose metabolism in $\mathrm{KK}-\mathrm{A}^{\mathrm{y}}$ mice ${ }^{(8)}$, to induce apoptosis through the inhibition of $N F-\kappa B$ activation in prostate epithelial cells $^{(9)}$, and to reduce adipocyte numbers and hypertrophy by increasing apoptosis through NF- $\mathrm{KB}$ activity in preadipocytes $^{(10)}$. Yajima et $a l .{ }^{(11,12)}$ reported that an isomerised hop extract and isohumulone reduced insulin resistance through the activation of $\operatorname{PPAR} \alpha$ and $\gamma$, and prevented high-fat (HF) diet-induced obesity through the inhibition of intestinal dietary fat absorption by inhibiting pancreatic lipase in rodents. The regulation of blood lipid levels and liver cholesterol and TAG concentrations in mice fed diets containing isohumulone might involve the activation of $\operatorname{PPAR} \alpha^{(13,14)}$. It has been reported that isohumulone improved hyperglycaemia and decreased body fat in Japanese subjects with prediabetes ${ }^{(15)}$. Namikoshi et al. ${ }^{(16)}$ reported that isohumulone ameliorated renal injury via an anti-oxidative effect in Dahl salt-sensitive rats. Thus, hop extracts, isomerised hop extracts, and compounds such as humulone and xanthohumol have various biological actions. There are many reports that the isomerised hop extracts produced by the brewing of beer prevent lifestyle-related diseases including obesity, hyperlipidaemia, fatty liver, insulin-resistant diabetes and hypertension. However, the actions of untreated hop extracts against obesity have yet to be clarified. In the present study, we examined the effects of a hop extract on obesity induced by feeding a HF diet long-term in mice.

\section{Materials and methods}

\section{Materials}

The hop (H. lupulus L.; Cannabaceae) water extract (lot. 080708AG) was supplied by Nihon Funmatsu Pharmacy

Abbreviations: ANP, atrial natriuretic peptide; HF, high fat; TC, total cholesterol. 
Company. Hopsteiner isomerised hop extract (batch no. IL-052001) was supplied by Dr Y. Miura (Central Laboratories for Key Technology, Kirin Brewery Company Limited. Voucher samples were deposited at the Division of Biochemical Pharmacology, Department of Basic Medical Research, Ehime University Graduate School of Medicine. An isomerised hop extract, a hop water extract, an ethylacetate-soluble fraction, a methanol-soluble fraction and a methanol-insoluble fraction were analysed by HPLC (GLIVER-HPLC System, JASCO Company) under the following conditions: monitoring wavelength, $317 \mathrm{~nm}$; flow rate, $1.0 \mathrm{ml} / \mathrm{min}$; mobile phase, solvents (a) methanol and (b) water; gradient profile, 0-15 min $20 \%$ methanol; 15-25 min 80\% methanol; column, TSK-GEL ODS$120 \mathrm{~T}(5 \mu \mathrm{m}, 150 \times 4.6 \mathrm{~mm}$ inside diameter, Toso Company); and column temperature, $40^{\circ} \mathrm{C}$. The HPLC profiles of the isomerised hop extract, hop water extract, ethylacetate-soluble fraction, methanol-soluble fraction and methanol-insoluble fraction are shown in Fig. 1. The TAG E-test, total cholesterol (TC) and NEFA C-test were purchased from Wako Pure Chemical Company Limited. Maize starch, casein, cellulose, soyabean oil, lard, mineral mixture (American Institute of Nutrition (AIN)-76) and vitamin mixture (AIN-76) were from Clea Japan Company. The standard diet AIN-93M (protein 13.9\% energy, fat $9.7 \%$ energy and carbohydrate $77.0 \%$ energy) (total $1577 \mathrm{~kJ} / 100 \mathrm{~g}$ diet $(377 \mathrm{kcal} / 100 \mathrm{~g}$ diet)) was purchased from Test Diet Company. Dulbecco's modified Eagle's medium and fetal bovine serum were purchased from Nissui Pharmacy Company and Gibo BRL, respectively. The antibiotic and antimycotic solution

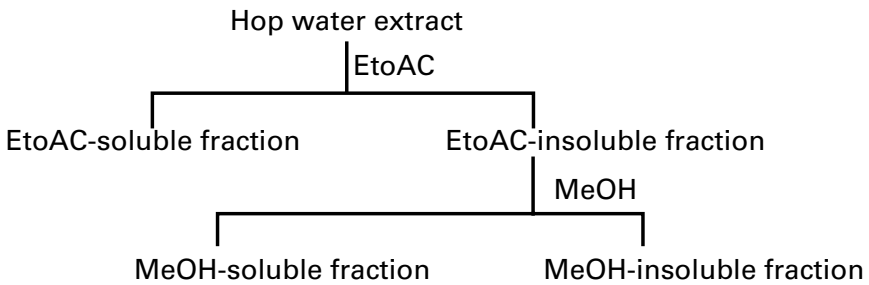

(a)

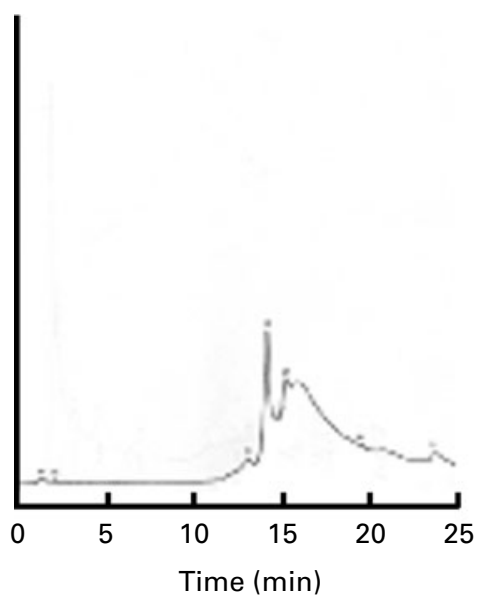

(d)

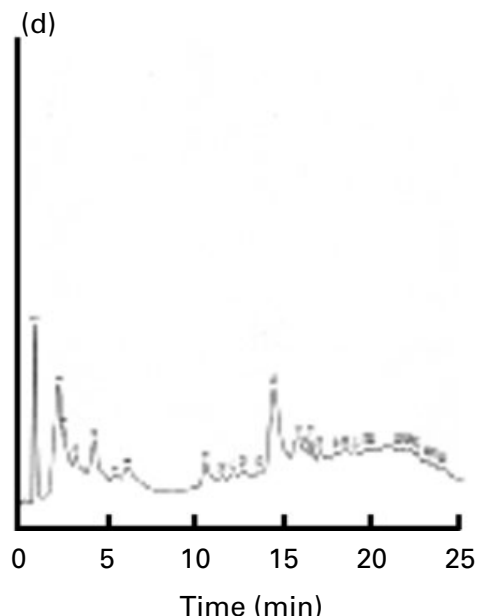

(b)

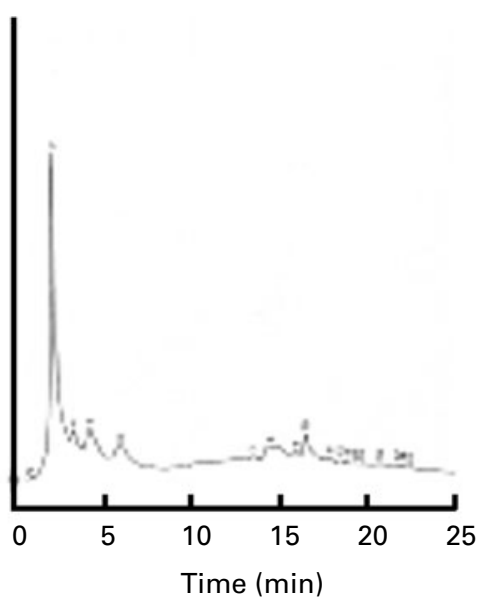

(c)

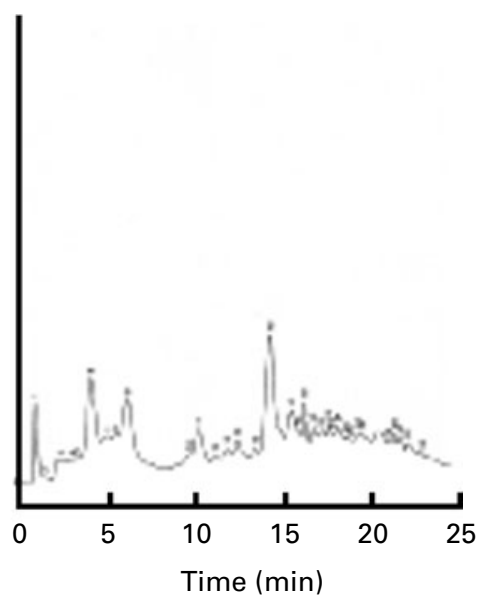

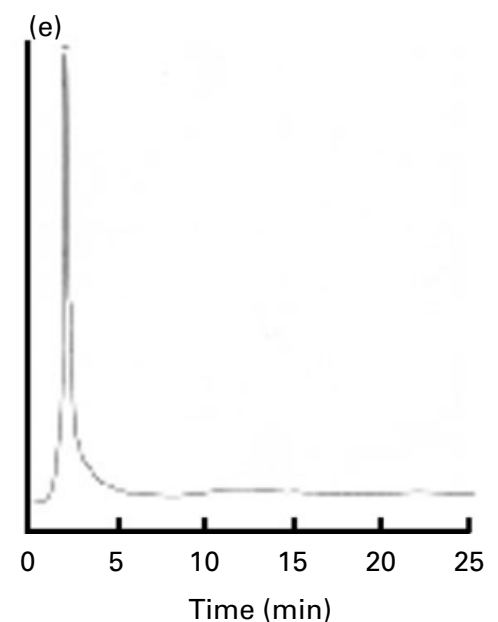

Fig. 1. HPLC profiles of the (a) isomerised hop extract, (b) hop extract, (c) ethyl acetate (EtOAc)-soluble fraction, (d) methanol (MeOH)-soluble fraction and (e) $\mathrm{MeOH}$-insoluble fraction. 
$(100 \times)$ containing 10000 units of penicillin, $10 \mathrm{mg}$ of streptomycin and $25 \mu \mathrm{g}$ of amphotericin $\mathrm{B} / \mathrm{ml}$ in $0.9 \% \mathrm{NaCl}$ was purchased from Sigma Company. The six-well and twelve-well culture plates were purchased from Corning, Inc.. The antiPPAR $\gamma$ rabbit monoclonal and anti- $\beta$-actin mouse antibodies were purchased from Cell Signaling Technology, Inc. and Sigma Company, respectively. Other chemicals were of reagent grade.

\section{Composition of diets}

The basic composition of the experimental HF diet was as follows (g/100 g food): maize starch 30 , casein 14 , sugar 10 , cellulose 5 , soyabean oil 4 , lard $32 \cdot 5$, mineral mixture 1 and vitamin mixture 1 (total $2284 \mathrm{~kJ} / 100 \mathrm{~g}$ diet $(546 \mathrm{kcal} / 100 \mathrm{~g}$ diet)). The composition of the other experimental diets is shown in Table 1 . To avoid the auto-oxidation of fat content, the feeds were stored at $-30^{\circ} \mathrm{C}$ and freshly prepared each day.

\section{Animals}

Male $\mathrm{C} 57 \mathrm{BL} / 6 \mathrm{~J}$ mice (4 weeks old) and male Balb/c mice (5 weeks old) obtained from Japan SLC Company were housed in a room with a $12 \mathrm{~h}$ light $-12 \mathrm{~h}$ dark cycle and controlled temperature and humidity. The animals had free access to food and water, and were used after 1 week of adaptation to the lighting conditions. Mice were treated according to the ethical guidelines of the Animal Center, Ehime University Graduate School of Medicine. The Animal Studies Committee of Ehime University approved the experimental protocol.

Body weight, liver and white adipose tissue weights, plasma lipids, and liver TAG and total cholesterol concentrations

Male C57BL/6J mice (4 weeks old) were divided into six groups that were matched for body weight, after 1 week of being fed laboratory pellet chow ad libitum. The control group was given the standard purified diet AIN-93M ad libitum during the experimental period. The mice consumed the HF diet, or the HF diet containing 2 or $5 \%$ hop extract for 20 weeks. Body weight was measured once a week and

Table 1. Composition of experimental high-fat (HF) diets

\begin{tabular}{|c|c|c|c|}
\hline $\mathrm{g} / 100 \mathrm{~g}$ & HF & $\begin{array}{l}\text { HF plus } 2 \% \\
\text { hop extract }\end{array}$ & $\begin{array}{l}\text { HF plus } 5 \% \\
\text { hop extract }\end{array}$ \\
\hline Maize starch & 30.0 & $28 \cdot 0$ & $25 \cdot 0$ \\
\hline Casein & $14 \cdot 0$ & $14 \cdot 0$ & $14 \cdot 0$ \\
\hline Sucrose & $10 \cdot 0$ & $10 \cdot 0$ & $10 \cdot 0$ \\
\hline Cellulose & 5.0 & $5 \cdot 0$ & $5 \cdot 0$ \\
\hline Soyabean oil & $4 \cdot 0$ & 4.0 & 4.0 \\
\hline Lard & 32.5 & 32.5 & 32.5 \\
\hline Mineral mixture & 3.5 & 3.5 & 3.5 \\
\hline Vitamin mixture & 1.0 & 1.0 & 1.0 \\
\hline Hop extract & 0.0 & $2 \cdot 0$ & 5.0 \\
\hline \multicolumn{4}{|l|}{ Energy } \\
\hline $\mathrm{kcal} / 100 \mathrm{~g}$ & 546 & 546 & 546 \\
\hline $\mathrm{kJ} / 100 \mathrm{~g}$ & 2284 & 2284 & 2284 \\
\hline
\end{tabular}

the total amount of food consumed was recorded weekly. After the mice had been fed these diets for 20 weeks, blood was taken by venous puncture under anaesthesia with diethyl ether. Then, the mice were killed with an overdose of diethyl ether. Experiments were performed in a ventilated room. The plasma was prepared by centrifugation and frozen at $-80^{\circ} \mathrm{C}$ for analysis. The plasma TAG, TC and NEFA concentrations were determined using the TAG E-test, TC E-test and NEFAtest kits. The liver and white adipose tissue were dissected and weighed. To measure the liver TAG and TC concentrations, liver ( $1 \mathrm{~g}$ ) was homogenised with distilled water $(10 \mathrm{ml})$. The liver TAG and TC concentrations were measured by the methods of Fletcher ${ }^{(17)}$ and Zak et al. ${ }^{(18)}$, respectively.

\section{TAG excretion in faeces of mice}

Male $\mathrm{C} 57 \mathrm{Bl} / 6 \mathrm{~J}$ mice ( 5 weeks old) were housed for 1 week in a room maintained at $25 \pm 1^{\circ} \mathrm{C}$ with $60 \%$ relative humidity. The mice consumed the HF diet or the HF diet containing 2 or $4 \%$ hop extracts for 2 weeks. Samples of faeces were obtained from each group at $24 \mathrm{~h}$ intervals for $4 \mathrm{~d}$, and the TAG in the faeces was measured by the method of Fletcher ${ }^{(17)}$.

\section{Pancreatic lipase activity (in vitro)}

The assay of pancreatic lipase activity in porcine pancreas was performed as described previously ${ }^{(19)}$. Enzyme activity ( $\mu \mathrm{mol}$ oleic acid released $/ \mathrm{ml}$ of reaction mixture per min) was expressed as a percentage of the value obtained with buffer alone (control).

\section{Histological examination}

White epididymal adipose tissues were fixed in buffered $10 \%$ formalin for at least $12 \mathrm{~h}$, and progressively dehydrated in solutions containing an increasing percentage of ethanol (70, 80, 95 and 100\%). They were then cleared in Histoclear (FUME HOOD, AS-ONE), embedded in paraffin under vacuum, sectioned 5- $\mu \mathrm{m}$ thick, deparaffinised, and stained with haematoxylin and eosin. Four different microscopic fields $($ magnification $100 \times$ ) per plate were photographed and more than 100 adipose cells were selected and their cell diameters measured.

\section{Oral glucose tolerance test}

The oral glucose tolerance test was performed at week 19 on mice fed the standard diet, the HF diet and the HF diet plus hop extract. Briefly, after at least $5 \mathrm{~h}$ of food deprivation, glucose $(100 \mathrm{mg} / \mathrm{mouse})$ was administered orally to the mice. Blood samples were taken from the tail at specific times and blood glucose concentrations were measured using GLUCOCARD ${ }^{\text {тм }}$ (GT-1640, Arkray).

\section{Water excretion}

The effect on water excretion in water-loaded mice was examined by the method of Hagino et al. ${ }^{(20)}$. Balb/c mice 
were housed individually in metabolic cages for 1 week, then administered the hop extract (100 or $500 \mathrm{mg} / \mathrm{kg}$ body weight) orally twice daily (08.00 and 19.00 hours) for $7 \mathrm{~d}$. After $16 \mathrm{~h}$ of food deprivation on day 8 , the hop extract was again administered orally. Then, $20 \mathrm{~s}$ later, sterile distilled water $(3 \mathrm{ml} / \mathrm{mouse}$; Otsuka Pharmacy Company Limited) was injected intraperitoneally. Urine volume was determined every hour for $6 \mathrm{~h}$ after the injection of distilled water.

\section{Adipocyte differentiation and lipid accumulation in 3T3-L1 adipocytes}

Cloned mouse 3T3-L1 fibroblasts, maintained at the Division of Biochemical Pharmacology, Department of Basic Medical Research, Ehime University Graduate School of Medicine, were used. The fibroblasts were maintained in Dulbecco's modified Eagle's medium supplemented with 10\% fetal bovine serum and penicillin (100 units $/ \mathrm{ml})$, streptomycin $(100 \mu \mathrm{g} / \mathrm{ml})$ and amphotericin B $(0.25 \mu \mathrm{g} / \mathrm{ml})$ (standard medium). They were grown to subconfluence in six-well or twelve-well culture plates, and fed $1 \mathrm{ml}$ of fresh standard medium containing $3 \mu \mathrm{m}$-dexamethazone, $0.6 \mathrm{~mm}$-1-methyl3 -isobutylxanthine and $1 \mu \mathrm{M}$-insulin (differentiation medium). After $48 \mathrm{~h}$, the differentiation medium was removed and the cells were treated with $1 \mu \mathrm{m}$-insulin and the ethylacetatesoluble, methanol-soluble or methanol-insoluble fractions of the hop extract. The medium was changed every other day, and the cells were cultured for $6 \mathrm{~d}$ in an atmosphere of $5 \%$ $\mathrm{CO}_{2}, 95 \%$ air at $37^{\circ} \mathrm{C}$. The accumulation of lipid droplets in the cytoplasm was determined by oil red $\mathrm{O}$ staining ${ }^{(21)}$, and four different microscopic fields were photographed.

\section{Proliferation of 3T3-L1 fibroblasts and 3T3-L1 adipocytes (in vitro)}

The confluent 3T3-L1 fibroblasts and differentiated 3T3-L1 adipocytes were cultured in Dulbecco's modified Eagle's medium, and the cells were exposed to the indicated amounts of hop extract for $24 \mathrm{~h}$. After the incubation period, the cell proliferation was determined using a Cell Counting kit (WST-1 assay; Wako Pure Chemical Company).

Immunoblotting of PPAR $\gamma$ in white adipose tissues of mice fed a high-fat diet and 3T3-L1 adipocytes

The white adipose tissues of mice fed a HF diet and the differentiated 3T3-L1 adipocytes were lysed with cell lysis buffer (20 mm-Tris-HCl (pH 7.5) containing $150 \mathrm{~mm}-\mathrm{NaCl}$, $1 \mathrm{~mm}$-EDTA, $1 \mathrm{~mm}$-ethylene glycol-bis (2-aminoethylether)$\mathrm{N}, \mathrm{N}, \mathrm{N}^{\prime}, \mathrm{N}^{\prime}$-tetraacetic acid, $1 \%$ Triton X-1001, $2.5 \mathrm{~mm}$-sodium

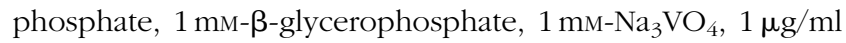
leupeptin and $1 \mathrm{~mm}$-phenylmethanesulphonyl fluoride). After centrifugation at $14000 \mathrm{~g}$ for $10 \mathrm{~min}$ at $4^{\circ} \mathrm{C}$, the supernatant was used for the measurement of PPAR $\gamma$ protein levels. The samples ( $80 \mu \mathrm{g}$ protein) were subjected to electrophoresis in a $7.5 \%$ polyacrylamide gel, and used for Western blotting with the anti-PPAR $\gamma$ rabbit monoclonal antibody and anti- $\beta$ actin mouse monoclonal antibody.

\section{Statistical analysis}

All values are expressed as means with their standard errors. Data were subjected to a one-way ANOVA, and differences among means were analysed using Fisher's protected least significant difference test. Differences were considered significant at $P<0.05$.

\section{Results}

Effects of hop extract on energy intake, body weight and tissue weight, and plasma and hepatic lipids in mice fed a high-fat diet

Mean daily food consumption per mouse for 20 weeks differed significantly $(P<0.05)$ between the standard diet (AIN-93M) (control)-fed group and the HF diet-fed group, being $42.6(\operatorname{sem} 0.50) \mathrm{kJ}(10.2(\operatorname{sem} 0.12) \mathrm{kcal})$ and 56.9 (SEM 0.79) kJ (13.6 (SEM 0.19) kcal), respectively.

However, it did not differ among mice fed the HF diet and the HF diet plus hop extract (2 or $5 \%$ ), being 56.9 (SEM 0.79$) \mathrm{kJ}$ (13.6 (sem 0.19) kcal; HF diet), 57.7 (SEM 0.87) kJ (13.8 (sem 0.21$) \mathrm{kcal}$; HF diet plus $2 \%$ hop extract) and 55.6 (sem 0.79) kJ (13.3 (sem 0.19) kcal; HF diet plus 5\% hop extract), respectively.

Fig. 2(a) shows changes in body weight. Mice fed the HF diet exhibited significant increases in body weight at 8-20 weeks compared to those fed the standard diet. The intake of the 2 or $5 \%$ hop extract significantly inhibited the increase in body weight caused by the HF diet at 10-20 weeks (Fig. 2(a)).

The weights of mesenteric and epididymal adipose tissue increased together with body weight in mice fed the HF diet compared with those on the standard diet, but the weights of liver and kidney were not significantly different between the two groups. The weights of liver, and mesenteric and epididymal adipose tissue in the HF diet-fed mice were significantly inhibited by the feeding of the 2 or $5 \%$ hop extract (Table 2). Furthermore, we examined the effects of the hop extract on cell diameter in mice fed the HF diet for 20 weeks. The adipocytes of the HF diet-fed mice were significantly larger than those of the standard diet-fed mice, being 74.68 (SEM 3.26) and 111.24 (SEM 4.38) $\mu \mathrm{m}$ in diameter, respectively. The increase in adipose tissue caused by the HF diet was significantly inhibited by the feeding of the 2 or $5 \%$ hop extract (Table 2 and Fig. 2(b)).

The PPAR $\gamma$ protein expression in HF diet-fed mice was greater than that in low-fat diet-fed mice. The PPAR $\gamma$ protein expression in mice fed HF diet plus 5\% hop extract significantly reduced compared to that in mice fed HF diet alone (control) (Fig. 2(c)).

Plasma TAG and NEFA concentrations did not differ significantly among mice fed the standard diet, HF diet, HF diet plus $2 \%$ hop extract and HF diet plus $5 \%$ hop extract. The plasma TC concentration was significantly increased at week 20 in mice on the HF diet (150.7 (SEM 9.3) mg/100 ml) compared to those fed the standard diet $(110 \cdot 4$ ( $\operatorname{sem} 5 \cdot 9) \mathrm{mg} / 100 \mathrm{ml})$. The increase in the plasma TC concentration caused by the HF diet was significantly inhibited by feeding the $2 \%$ hop extract (Table 3). 
(a)

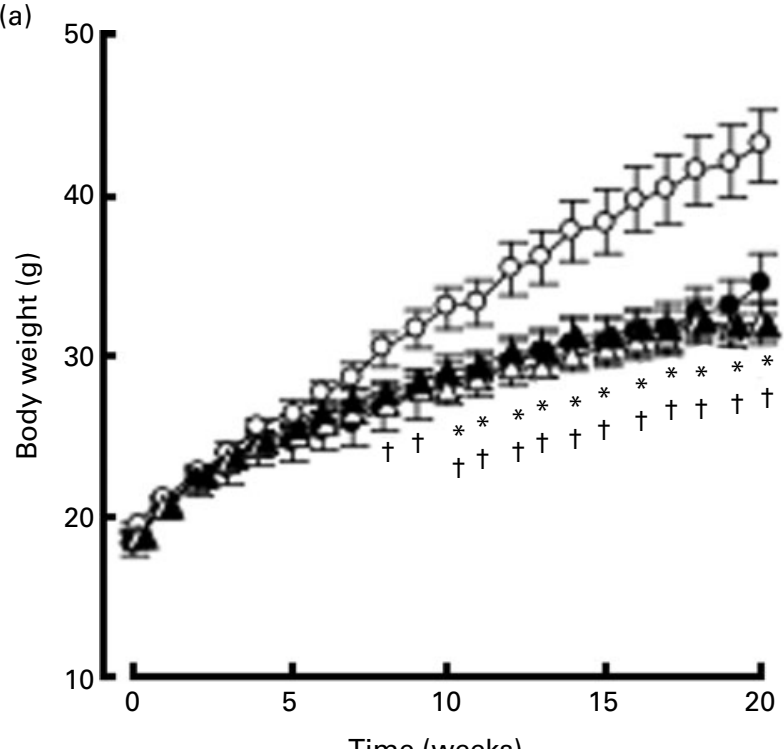

(b)

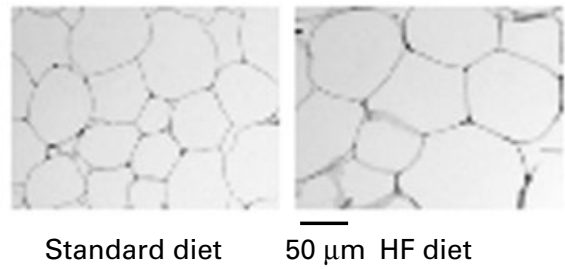

(AIN-93M)

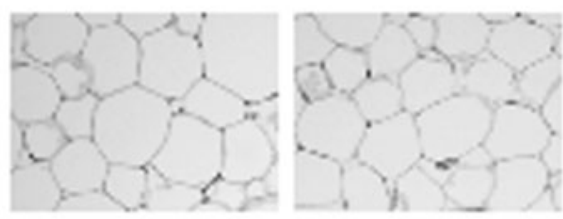

HF plus $2 \%$ hop extract
HF plus $5 \%$ hop extract (c)

Standard diet HP diet
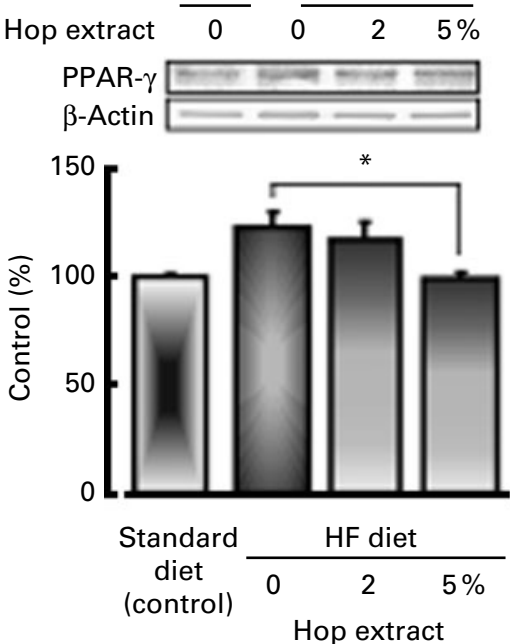

(d) 400 r

Fig. 2. Effects of the hop extract on (a) body weight, (b) adipocyte size, (c) PPARy protein expression in adipose tissues and (d) plasma glucose levels in the oral glucose tolerance test in mice fed a high-fat (HF) diet for 20 weeks. (a), (c) and (d) Values are means, with their standard errors represented by vertical bars ( $n 10$ mice). * Mean values were significantly different from those of the HF diet-fed groups ( $-\circ, \mathrm{HF}$ diet; $\neg-$, HF diet plus $2 \%$ hop extract; $\neg \leftarrow$, HF diet plus $5 \%$ hop extract) $(P<0.05)$. † Mean values were significantly different from those of the standard diet (AIN-93M, $\longrightarrow$ )-fed groups $(P<0.05)$. (b) Micrographs showing adipocytes in mice fed the standard diet, HF diet, HF diet plus $2 \%$ hop extract and HF diet plus $5 \%$ hop extract.

Table 2. Effects of hop extract on the weight of liver, kidney, mesenteric adipose and epididymal adipose tissues, and cell diameter in white adipose tissue in mice fed a high-fat (HF) diet for 20 weeks

(Mean values with their standard errors, $n 10$ mice)

\begin{tabular}{|c|c|c|c|c|c|c|c|c|}
\hline & \multicolumn{2}{|c|}{$\begin{array}{l}\text { Standard diet } \\
\text { (AIN-93M) }\end{array}$} & \multicolumn{2}{|c|}{ HF diet } & \multicolumn{2}{|c|}{$\begin{array}{l}\text { HF plus } 2 \% \\
\text { hop extract }\end{array}$} & \multicolumn{2}{|c|}{$\begin{array}{l}\text { HF plus } 5 \% \\
\text { hop extract }\end{array}$} \\
\hline & Mean & SEM & Mean & SEM & Mean & SEM & Mean & SEM \\
\hline Liver $(\mathrm{g})$ & 1.32 & 0.08 & 1.52 & 0.15 & $1 \cdot 14^{\star}$ & 0.04 & $1 \cdot 15^{*}$ & 0.05 \\
\hline Kidney (g) & 0.29 & 0.02 & 0.33 & 0.01 & 0.35 & 0.01 & 0.32 & 0.01 \\
\hline Mesenteric adipose tissue (g) & $0.39^{*}$ & 0.05 & 0.97 & 0.16 & $0.21^{*}$ & 0.04 & $0.22^{*}$ & 0.03 \\
\hline Epididymal adipose tissue (g) & $1 \cdot 17^{*}$ & 0.14 & $2 \cdot 14$ & 0.23 & $0.88^{*}$ & $0 \cdot 12$ & $0.96^{*}$ & 0.12 \\
\hline Adipocyte diameter $(\mu \mathrm{m})$ & $74.68^{*}$ & 3.26 & $111 \cdot 24$ & 4.38 & $71 \cdot 84^{*}$ & 3.89 & $76 \cdot 43^{\star}$ & 2.80 \\
\hline
\end{tabular}

${ }^{*}$ Mean values were significantly different from those of the HF diet-fed group $(P<0.05)$. 
Table 3. Effects of hop extract on plasma TAG, total cholesterol (TC) and NEFA levels, and liver TAG and TC concentrations in mice fed a high-fat (HF) diet for 20 weeks

(Mean values with their standard errors, $n 10$ mice)

\begin{tabular}{|c|c|c|c|c|c|c|c|c|}
\hline & \multicolumn{2}{|c|}{$\begin{array}{l}\text { Standard diet } \\
\text { (AIN-93M) }\end{array}$} & \multicolumn{2}{|c|}{ HF diet } & \multicolumn{2}{|c|}{$\begin{array}{l}\text { HF plus } 2 \% \\
\text { hop extract }\end{array}$} & \multicolumn{2}{|c|}{$\begin{array}{l}\text { HF plus } 5 \% \\
\text { hop extract }\end{array}$} \\
\hline & Mean & SEM & Mean & SEM & Mean & SEM & Mean & SEM \\
\hline \multicolumn{9}{|l|}{ Plasma lipids } \\
\hline TAG (mg/100 ml) & $60 \cdot 8$ & 5.9 & $62 \cdot 9$ & 4.4 & $49 \cdot 3$ & $2 \cdot 1$ & $51 \cdot 6$ & $2 \cdot 4$ \\
\hline $\mathrm{TC}(\mathrm{mg} / 100 \mathrm{ml})$ & $110 \cdot 4^{\star}$ & 5.9 & $150 \cdot 7$ & $9 \cdot 3$ & $108 \cdot 6^{\star}$ & 3.4 & $132 \cdot 6$ & 4.6 \\
\hline $\operatorname{NEFA}(\mu \mathrm{M})$ & 0.84 & 0.06 & 0.75 & 0.06 & 0.59 & 0.03 & 0.63 & 0.03 \\
\hline \multicolumn{9}{|l|}{ Liver lipids } \\
\hline TAG (mg/g liver) & $34 \cdot 9^{*}$ & 4.5 & $66 \cdot 3$ & $7 \cdot 8$ & $18 \cdot 4^{\star}$ & 1.6 & $22 \cdot 5^{\star}$ & $5 \cdot 1$ \\
\hline TC (mg/g liver) & $4 \cdot 29^{*}$ & 0.29 & 6.40 & 0.71 & $4 \cdot 23^{*}$ & $0 \cdot 18$ & $4 \cdot 70^{\star}$ & 0.24 \\
\hline
\end{tabular}

* Mean values were significantly different from those of the HF diet-fed group $(P<0.05)$

The liver concentrations of lipids (TAG and TC) were significantly greater in the HF diet-fed group than the standard diet-fed group, being $66.3($ SEM 7.8$) \mathrm{mg} / \mathrm{g}$ (TAG) and 6.40 (SEM 0.71$) \mathrm{mg} / \mathrm{g}$ (TC), and 34.9 (SEM 4.5$) \mathrm{mg} / \mathrm{g}$ (TAG) and 4.29 (SEM 0.29) $\mathrm{mg} / \mathrm{g}$ (TC), respectively. The feeding of the HF diet plus $2 \%$ hop extract, or HF diet plus 5\% hop extract significantly inhibited the increase in liver TAG and TC levels in the HF diet-fed group (Table 3).

\section{Effects of hop extract on fat excretion in faeces of mice fed} a high-fat diet

The dry weight $(0.51 \quad$ (SEM 0.05$) \mathrm{g} /$ mouse per d) of faeces collected during $4 \mathrm{~d}$ at week 2 in mice fed the HF diet was significantly lower than that in mice fed the low-fat diet $(0.88(\operatorname{sem} 0.05) \mathrm{g} /$ mouse per d). The dry weight of faeces did not differ between the HF diet-fed mice and HF diet plus hop extract-fed mice (data not shown). The TAG content of faeces was not significantly different between the standard diet and HF diet groups. The TAG content in faeces was not significantly different among the HF diet group, HF diet plus $2 \%$ and 5\% hop extract-diet groups, being 0.33 (sem 0.02$) \mathrm{mg} / \mathrm{mouse}$ per $\mathrm{d}$ (HF diet alone), 0.34 (SEM 0.02$) \mathrm{mg} / \mathrm{mouse}$ per $\mathrm{d}$ (HF diet plus $2 \%$ hop extract) and $0.41(\operatorname{sem} 0.07) \mathrm{mg} /$ mouse per $\mathrm{d}$ (HF diet plus $5 \%$ hop extract).

Effects of hop extract on plasma glucose levels in the oral glucose tolerance test in mice fed a high-fat diet

Fig. 2(c) shows the time course of the change in the plasma glucose level after the oral administration of glucose ( $100 \mathrm{mg} /$ mouse). A maximum level was reached at $15 \mathrm{~min}$. The HF diet plus 2 or $5 \%$ hop extract significantly reduced the elevated plasma glucose level 30,60 or $120 \mathrm{~min}$ after the administration of glucose compared with the HF diet alone (Fig. 2(d).

\section{Effects of hop extract on pancreatic lipase activity (in vitro)}

Hop extract had no effect on the pancreatic lipase activity; the percentage activity was 97.6 (SEM 5.96)\% at $50 \mu \mathrm{g} / \mathrm{ml}$,
$90 \cdot 4(\operatorname{sem} 4 \cdot 41) \%$ at $100 \mu \mathrm{g} / \mathrm{ml}, 90 \cdot 5(\operatorname{sem} 5.93) \%$ at $500 \mu \mathrm{g} /$ $\mathrm{ml}, 93.4(\operatorname{sem} 4.33) \%$ at $1000 \mu \mathrm{g} / \mathrm{ml}$ and $101.9(\operatorname{sem~} 3.85) \%$ at $2000 \mu \mathrm{g} / \mathrm{ml}$, respectively.

\section{Effects of hop extract on water excretion in water-loaded mice}

Urine volume was significantly increased 4,5 and $6 \mathrm{~h}$ after the intraperitoneal injection of distilled water $(3 \mathrm{ml} / \mathrm{mouse})$. The hop extract $(500 \mathrm{mg} / \mathrm{kg}$, twice daily for $7 \mathrm{~d})$ significantly enhanced water excretion at 3 and 4 h (Fig. 3).

\section{Effects of hop extract on proliferation in 3T3-L1 fibroblasts and 3T3-L1 adipocytes}

The hop extract did not inhibit the cell proliferation in 3T3-L1 fibroblast and adipocytes (data not shown). The cell number in 3T3-L1 adipocytes was not reduced by the treatment of hop extract under the observation of microscope (data not shown)

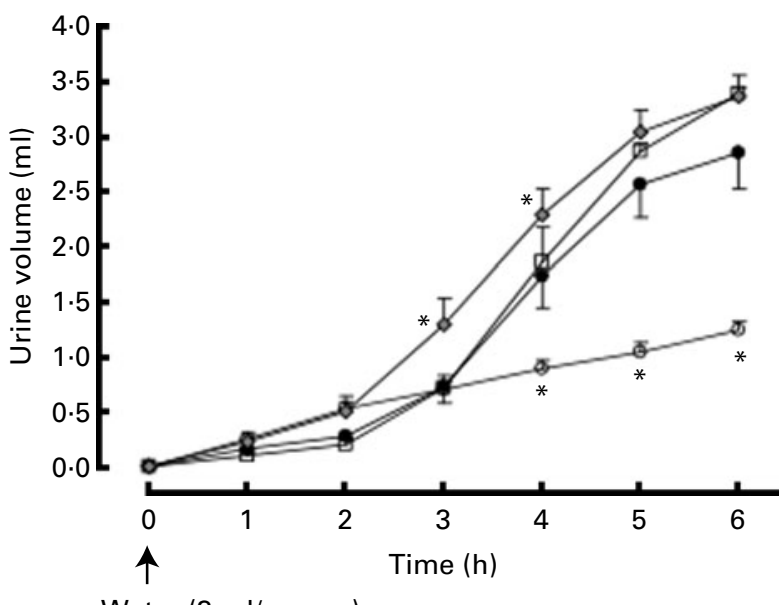

Fig. 3. Effects of the hop extract on water excretion in water-loaded mice. Values are means, with their standard errors represented by vertical bars (n 6 mice). * Mean values were significantly different from those of the water-loaded mice $(P<0.05)$. O, Normal; $\bullet$, water-loaded mice (control); $\square$, water-loaded mice plus hop extract $(100 \mathrm{mg} / \mathrm{kg}$, twice daily); $\diamond$, water-loaded mice plus hop extract $(500 \mathrm{mg} / \mathrm{kg}$, twice daily). 
(a)

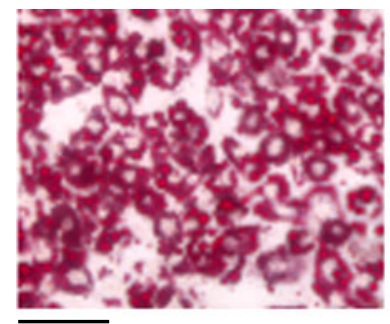

$100 \mu \mathrm{m}$

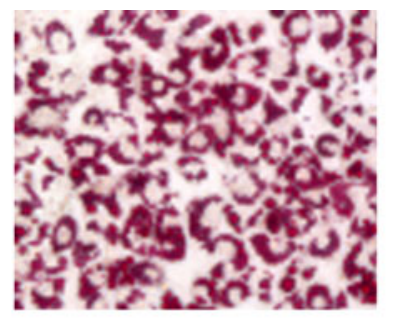

Hop water extract $(500 \mu \mathrm{g} / \mathrm{ml})$

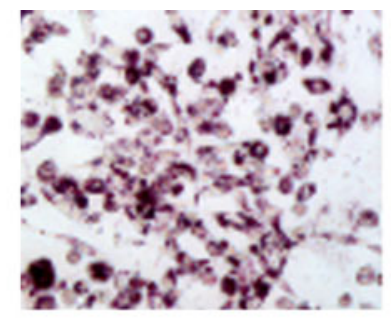

EtOAc-soluble fraction $(250 \mu \mathrm{g} / \mathrm{ml})$

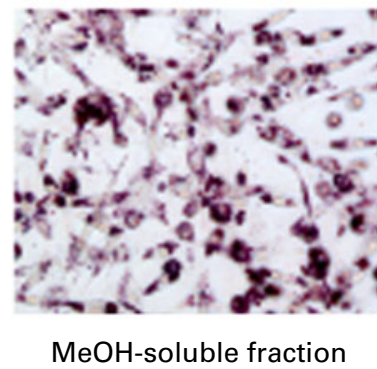

$(250 \mu \mathrm{g} / \mathrm{ml})$

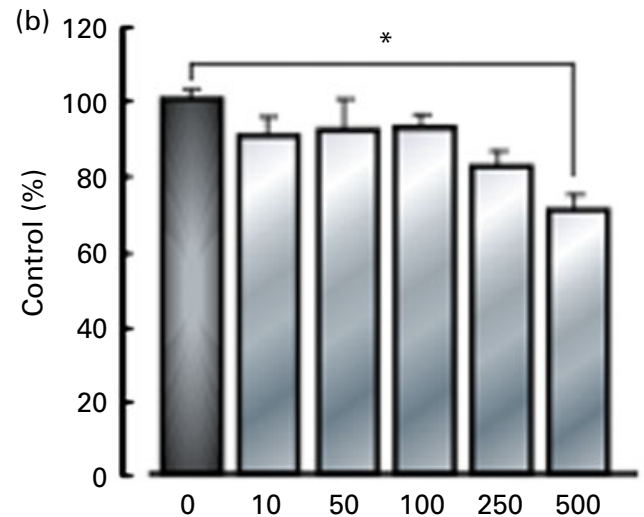

Hop water extract $(\mu \mathrm{g} / \mathrm{ml})$

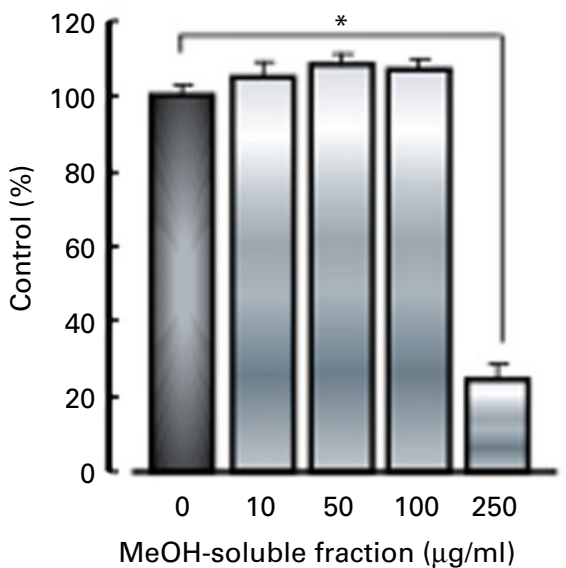

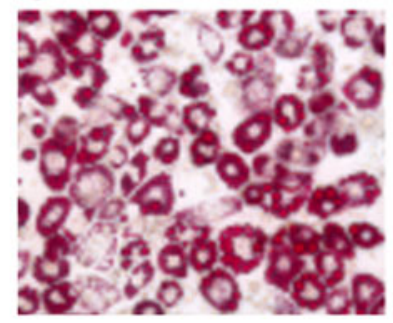

$\mathrm{MeOH}$-insoluble fraction $(250 \mu \mathrm{g} / \mathrm{ml})$

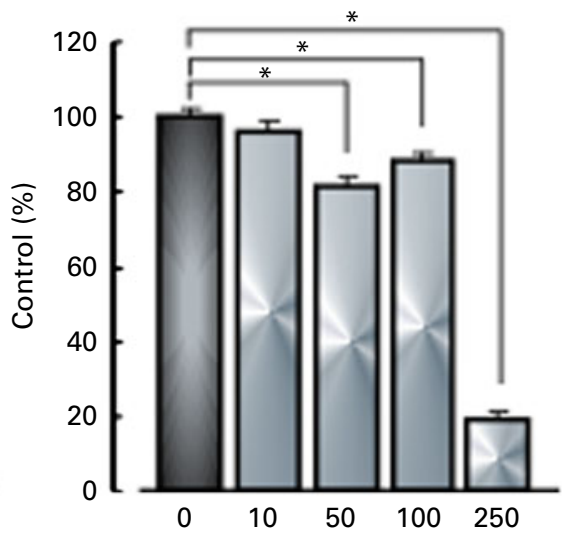

EtOAc-soluble fraction $(\mu \mathrm{g} / \mathrm{ml})$

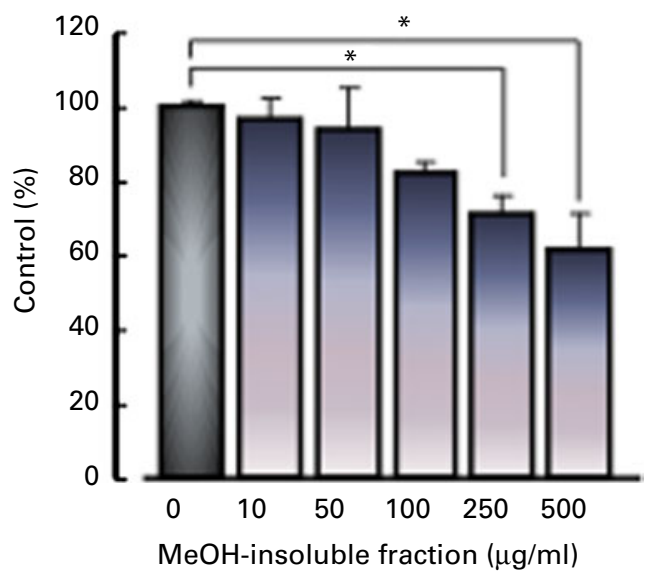

Fig. 4. Effects of various fractions of the hop extract on lipid accumulation in 3T3-L1 adipocytes. (a) Micrographs showing 3T3-L1 adipocytes treated with $1 \mu \mathrm{M}-$ insulin, insulin plus hop water extract $(500 \mu \mathrm{g} / \mathrm{ml})$, insulin plus ethyl acetate (EtOAc)-soluble fraction $(250 \mu \mathrm{g} / \mathrm{ml})$, insulin plus methanol (MeOH)-soluble fraction $(250 \mu \mathrm{g} / \mathrm{ml})$ and insulin plus $\mathrm{MeOH}$-insoluble fraction $(250 \mu \mathrm{g} / \mathrm{ml})$. (b) Values are means, with their standard errors represented by vertical bars $(n 4$ experiments). ${ }^{*}$ Mean values were significantly different from those of the insulin alone (control) $(P<0.05)$. (A colour version of this figure can be found online at http://www.journals.cambridge.org/bjn) 
Effects of various fractions of the hop extract on lipid accumulation, and PPAR $\gamma$ expression in 3T3-L1 adipocytes

3T3-L1 fibroblasts were cultured with various fractions (hop water extract, ethyl acetate-soluble fraction, methanol-soluble fraction and methanol-insoluble fraction) for $48 \mathrm{~h}$ in the presence of $3 \mu \mathrm{m}$-dexamethazone, 0.6 mM-1-methyl-3-isobutylxanthine and $1 \mu \mathrm{M}$-insulin (differentiation medium), and then cultured with the standard medium containing $1 \mu \mathrm{m}$-insulin with or without the various fractions for $6 \mathrm{~d}$. The hop water extract $(500 \mu \mathrm{g} / \mathrm{ml})$, ethyl acetate-soluble fraction $(50,100$ or $250 \mu \mathrm{g} / \mathrm{ml}$ ), methanol-soluble fraction $(250 \mu \mathrm{g} / \mathrm{ml})$ and methanol-insoluble fraction ( 250 or $500 \mu \mathrm{g} / \mathrm{ml}$ ), all inhibited the accumulation of lipid droplets (TAG contents) in the cytoplasm in the differentiated adipocytes (Fig. 4).

PPAR $y$ expression was stimulated by the differentiation of 3T3-L1 fibroblasts into adipocytes. The increase in PPAR $y$ expression in the differentiated adipocytes tended to be reduced by the hop extract $(500 \mu \mathrm{g} / \mathrm{ml})$ and methanol-insoluble fraction $(250$ or $500 \mu \mathrm{g} / \mathrm{ml})$. The ethyl acetate-soluble fraction $(250 \mu \mathrm{g} / \mathrm{ml})$ and methanol-soluble fraction $(250 \mu \mathrm{g} / \mathrm{ml})$ significantly inhibited the increase (Fig. 5).
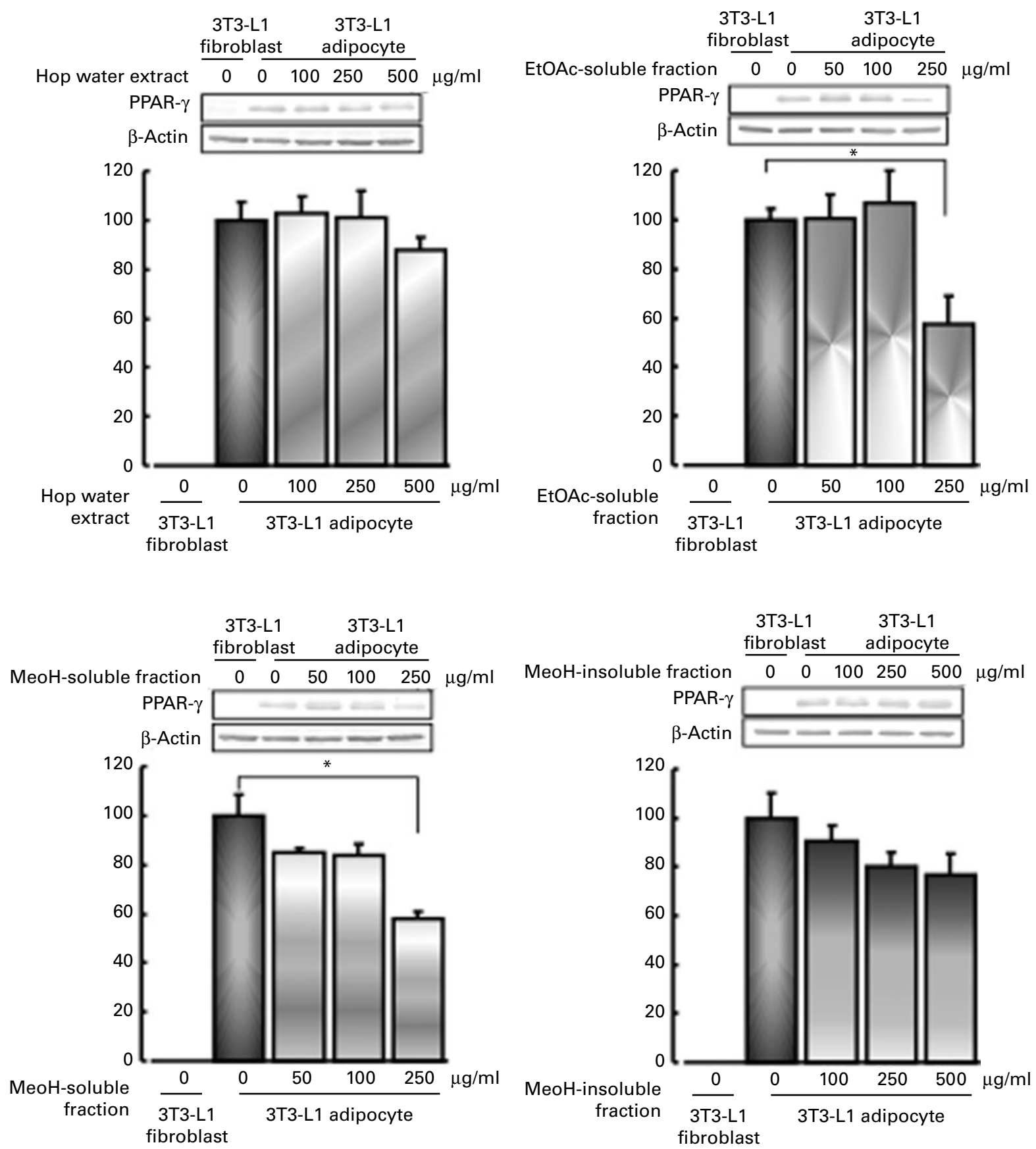

Fig. 5. Effects of various fractions of the hop extract on PPAR $y$ expression in 3T3-L1 adipocytes. Values are means, with their standard errors represented by vertical bars ( $n 4$ experiments). ${ }^{*}$ Mean values were significantly different from those of the insulin alone (control) $(P<0 \cdot 05)$. EtOAc, ethyl acetate; MeOH, methanol. 


\section{Discussion}

There are a number of studies describing HF diet-induced obesity $^{(22-25)}$. Obesity is closely associated with several metabolic disorders including insulin-resistant diabetes mellitus, hyperlipidaemia, hypertension and atherosclerosis. These factors can increase the risk of $\mathrm{CHD}^{(26,27)}$. A hop extract had no effect on faecal fat excretion in mice fed a HF diet (in vivo), and pancreatic lipase activity (in vitro). Therefore, the anti-obesity action of hop extract could not be explained by the inhibition of dietary fat absorption from the small intestine by inhibiting pancreatic lipase activity. Since the hop extract had no effect on lipolysis and epinephrineinduced lipolysis (data not shown), the anti-obesity action of hop extract could not be explained by the stimulation of lipolytic action in adipose tissues. Obese patients were reported to have an impaired rise in NEFA following injections of epinephrine and to excrete water more slowly than normal subjects ${ }^{(28)}$. Furthermore, obesity is associated with expanded circulatory volume and an increased extracellular fluid ratio, and enhanced body $\mathrm{Na}$ content ${ }^{(29,30)}$. The alterations in the renin-angiotensin system are closely associated with the development of hypertension in obesity ${ }^{(31)}$. Laragh $^{(32)}$ reported that atrial natriuretic peptide (ANP) acted by promoting diuresis, natriuesis and vasodilation and by suppressing the activity of the renin-aldosterone system. De Pergola et al. ${ }^{(33)}$ reported that the natriuretic response in obese women was found to be reduced by the treatment with intravenous injection of ANP. Valensi et al. ${ }^{(34)}$ reported that the water loaded-induced inhibition of anti-diuretic hormone secretion and stimulation of ANP secretion or ANP activity was more defective in obese women with a swelling syndrome. In a preliminary experiment, the hop extract stimulated water excretion in water-loaded mice. Therefore, the stimulation of urinary excretion of hop extract in waterloading mice may be due to the secretion or activation of ANP; however, the detail is unknown. Further studies are needed to clarify the mechanism of hop extract on the stimulation of urinary excretion. Then, we examined its effects on obesity and the oral glucose tolerance test in mice fed a HF diet long-term. The hop extract reduced obesity, adipose tissue weight and adipocyte hyperplasia. Furthermore, it inhibited the increase in liver lipids (TC and TAG), and plasma TC caused by the diet. Oosterveer et al. ${ }^{(35)}$ reported that mRNA levels for the enzyme of cholesterol biosynthesis (3-hydroxy-3-methylglutary-CoA synthetase 1, 3-hydroxy-3methylglutaryl-CoA reductase) of the liver in $\mathrm{HF}$ diet-fed mice were higher than those in chow-fed mice. Furthermore, they reported that HF diet feeding increased cholesterol synthesis from $\left[1-{ }^{13} \mathrm{C}\right]$-acetate compared to chow-fed mice. In the present study, we found that plasma and liver cholesterol levels increased by the feeding of a HF diet long-term. Therefore, the elevations in plasma and liver cholesterol levels might be due to the increase in hepatic cholesterogenic gene expression. Further studies are needed to examine the effects of hop extract on hepatic choleterogenic enzymes (3-hydroxy-3-methylglutaryl-CoA synthetase and HMG-CoA reductase). Obesity is closely associated with insulin-resistant diabetes mellitus ${ }^{(27,36)}$. We also found that long-term feeding of a HF diet to mice caused obesity and glucose intolerance (reduction in insulin sensitivity), with increases in fat volume, fat size and PPAR $\gamma$ protein ${ }^{(37)}$. The feeding of the hop extract improved the glucose intolerance caused by the consumption of a HF diet for 19 weeks. Obesity is a condition in which adipocytes accumulate a large amount of fat and become enlarged. Adipocytes play a critical role in lipid homeostasis and the energy balance. Adipocyte differentiation is a complex process by which fibroblastlike undifferentiated cells are converted into cells that accumulate lipid droplets. PPAR $\gamma$ (a nuclear hormone receptor) plays a critical role in adipogenesis, is essential to lipid and glucose homeostasis, and is predominantly expressed in adipose tissue ${ }^{(38,39)}$. In the present study, the hop extract inhibited the increase in PPAR $y$ protein expression in the adipose tissues of mice fed a HF diet. PPAR $\gamma$ agonists, thiazolidinediones including pioglitazone and rosiglitazone, are widely used in causes of type 2 diabetes mellitus to improve insulin sensitivity by inducing the expression of genes involved in adipocyte differentiation, lipid and glucose uptake, and fatty acid storage ${ }^{(40-42)}$. On the other hand, T0070907, a potent and selective PPAR $\gamma$ antagonist, was reported to inhibit lipid accumulation in 3T3-L1 cells ${ }^{(43)}$. To clarify the mechanism of action of hop extracts, we examined the effects of various fractions of an extract on lipid accumulation, adipocyte differentiation and the expression of PPAR $\gamma$ in 3T3-L1 preadipocytes (in vitro). The hop extract itself, the ethylacetate-soluble fraction and the methanol-soluble fraction strongly inhibited the adipocyte differentiation, lipid accumulation and PPAR $\gamma$ expression. It therefore seems likely that the anti-obesity action of the extract is partly due to stimulation of the excretion of water from the body, and a reduction in the accumulation of lipids in adipocytes through the inhibition of PPAR $\gamma$ expression, which might improve glucose intolerance caused by obesity. Experiments are now in progress to isolate the active substance(s) of hop extract. It is concluded that hop extracts might be useful for preventing obesity and/or glucose intolerance caused by a HF diet.

\section{Acknowledgements}

The authors thank Dr Y. Miura (Kirin Brewery Company Limited) for the supply of isomerised hop extract. Animal experiments were performed according to the ethical guidelines of the Animal Experimentation Center, Ehime University and Japanese Pharmacological Society, and guide for the care and use of laboratory animals of the National Institutes of Health. The animal experiments were approved by the Ethics Committee on Animal Experimentation, Ehime University (approval number: YA-8-1). M. S. performed all the experimental analyses and helped write the manuscript. Y. K. designed the experiment, conducted all the experimental work and helped write the manuscript with M. S. The authors declare that they have no conflicts of interest. This work was supported by Research Grants from Nihon Funmatsu Pharmacy Company. 


\section{References}

1. Kurasawa T, Chikaraishi Y, Naito A, et al. (2005) Effect of Humulus lupulus on gastric secretion in a rat pylorus-ligated model. Biol Pharm Bull 28, 353-357.

2. Heyerick A, Vervarcke S, Depypere H, et al. (2006) A first prospective, randomized, double-blind, placebo-controlled study on the use of a standardized hop extract to alleviate menopausal discomforts. Maturitas 54, 164-175.

3. Yamaguchi N, Satoh-Yamaguchi K \& Ono M (2009) In vitro evaluation of antibacterial, anticollagenase, and antioxidant activities of hop components (Humulus lupulus) addressing acne vulgaris. Phytomedicine 16, 369-376.

4. Shimamura M, Hazato T, Ashino H, et al. (2001) Inhibition of angiogenesis by humulone, a bitter acid from beer hop. Biochem Biophys Res Commun 289, 220-224.

5. Yasukawa K, Takeuchi M \& Takido M (1995) Humulone, a bitter in the hop, inhibits tumor promotion by 12 -O-tetradecanoylphorbol-13-acetate in two-stage carcinogenesis in mouse skin. Oncology 52, 156-158.

6. Yamamoto K, Wang J, Yamamoto S, et al. (2000) Suppression of cylooxygenase-2 gene transcription by humulone of beer hop extract studies with reference to glucocorticoid. FEBS Lett 465, 103-106.

7. Lee JC, Kundu JK, Hwang DM, et al. (2007) Humulone inhibits phorbol ester-induced COX-2 expression in mouse skin by blocking activation of NF-kB and AP-1: IкB kinase and c-Jun-N-terminal kinase as respective potential upstream targets. Carcinogenesis 28, 1491-1498.

8. Nozawa N (2005) Xanthohumol, the chalcone from beer hops (Humulus lupulus L.), is the ligand for farnesoid $\mathrm{X}$ receptor and ameliorates lipid and glucose metabolism in KK-A $\mathrm{A}^{\mathrm{y}}$ mice. Biochem Biophys Res Commun 336, 754-761.

9. Colgate EC, Miranda CL, Stevens JF, et al. (2007) Xanthohumol, a prenylflavonoid derived from hops induces apoptosis and inhibits NF-kappaB activation in prostate epithelial cells. Cancer Lett 246, 201-209.

10. Mendes V, Monterio R, Pestana D, et al. (2008) Xanthohumol influences preadipocyte differentiation: implication of antiproliferative and apoptotic effects. J Agric Food Chem 56, 11631-11637.

11. Yajima H, Ikeshima E, Shiraki M, et al. (2004) Isohumulones, bitter acids derived from hops, activate both peroxisome proliferators-activated receptor $\alpha$ and $\gamma$ and reduce insulin resistance. J Biol Chem 279, 33456-33462.

12. Yajima H, Noguchi $\mathrm{T}$, Ikeshima E, et al. (2005) Prevention of diet-induced obesity by dietary isomerized hop extract containing isohumulones, in rodents. Int J Obes 29, 991-997.

13. Miura Y, Hosono M, Oyamada C, et al. (2005) Dietary isohumulones, the bitter components of beer, raise plasma HDL-cholesterol levels and reduce liver cholesterol and triacylglycerol contents similar to PPAR $\alpha$ activation in C57BL/6 mice. Br J Nutr 93, 559-567.

14. Shimura M, Hasumi A, Minato T, et al. (2005) Isohumulones modulate blood lipid status through the activation of PPAR $\alpha$. Biochim Biopys Acta 1736, 51-60.

15. Obara K, Mizutani M, Hitomi Y, et al. (2009) Isohumulones, the bitter component of beer, improve hyperglycemia and decrease body fat in Japanese subjects with prediabetes. Clin Nutr 28, 278-284.

16. Namikoshi T, Tomita N, Fujimoto S, et al. (2007) Isohumulones derived from hops ameliorate renal injury via an anti-oxidative effect in Dahl salt-sensitive rats. Hypertens Res 30, 175-184.
17. Fletcher MJ (1968) A colorimetric method for estimating serum triglycerides. Clin Chem Acta 22, 393-397.

18. Zak B, Dickman RC, White EG, et al. (1954) Rapid estimation of free and total cholesterol. Am J Clin Pathol 24, 1307-1315.

19. Han L-K, Takaku T, Li J, et al. (1999) Anti-obesity action of oolong tea. Int J Obesity 23, 98-105.

20. Hagino K, Oshige H, Ozawa K, et al. (1991) Effect of XKJ-001, a crude drug preparation, on body water distribution and water excretion in mice. Yakugaku Zasshi 111 293-298 (In Japanese).

21. Novikoff AB, Novikoff PM, Rosen OM, et al. (1980) Organelle relationships in cultured 3T3-L1 preadipocytes. J Cell Biol 87, 180-196.

22. Flatt JP (1987) The difference in the storage capacities for carbohydrate and for fat, and its implications in the regulation of body weight. Ann N Y Acad Sci 499, $104-123$.

23. Awad AB, Bernardis LL \& Fink CS (1990) Failure to demonstrate an effect of dietary fatty acid composition on body weight, body consumption and parameters of lipid metabolism in mature rats. J Nutr 120, 1277-1282.

24. Shimomura Y, Tamura T \& Suzuki M (1990) Less body fat accumulation in rats fed a safflower oil diet than in rats fed a beef tallow diet. J Nutr 120, 1291-1296.

25. Hill JO, Peters JC, Lin D, et al. (1993) Lipid accumulation and body fat distribution is influenced by the type of dietary fed to rats. Int J Obes 17, 223-226.

26. Plutzky J (2000) Emerging concepts in metabolic abnormalities associated with coronary artery disease. Curr Opin Cardiol 15, 416-421.

27. Reaven GM (1988) Role of insulin resistance on human disease. Diabetes 37, 1595-1607.

28. Gordon ES, Glodberg M \& Chosy GJ (1963) A new concept in the treatment of obesity. JAMA 186, 50-60.

29. Messerli FH, Christie B \& De Carvalho JGR (1981) Obesity and essential hypertension: hemodynamics, intravascular volume, sodium excretion and plasma renin activity. Arch Intern Med 141, 81-85.

30. Rocchini AP, Katch V \& Kvselis D (1989) Insulin and renal sodium retension in obese adolescents. Hypertension $\mathbf{1 4}$, 367-374.

31. Landberg L (1992) Hyperinslinemia: possible role in obesity-induced hypertension. Hypertension 19, Suppl. 1, 61-66.

32. Laragh JH (1985) Atrial natriuretic hormone, the reninealdosterone axis, and blood pressure-electrolyte homeostasis. NEngl J Med 313, 1330-1340.

33. De Pergola G, Garruti G, Giorgino F, et al. (1994) Reduced effectiveness of atrial natriuretic factor in pre-menopausal obese women. Int J Obes 18, 93-97.

34. Valensi P, Sibony-Prat J, Behar A, et al. (1997) Impairment of antidiuretic hormone and atrial natriuretic peptide regulation in the obese woman with a swelling syndrome and an increase in capillary permeability to albumin. Int $J$ Obes 21, 651-657.

35. Oosterveer MH, van Dijk TH, Tietge UJF, et al. (2009) High fat feeding induces hepatic fatty acid elongation in mice. PLoS One 4, e6066.

36. Kanh BB \& Flier JS (2000) Obesity and insulin resistance. J Clin Invest 106, 473-481.

37. Sumiyoshi M, Sakanaka M \& Kimura Y (2006) Chronic intake of high-fat and high-sucrose diets differentially affects glucose intolerance in mice. J Nutr 136, 582-587. 
38. Tontonoz P, Hu E \& Spiegelman BM (1994) Stimulation of adipogenesis in fibroblast by PPAR gamma 2, a lipidactivated transcription factor. Cell 79, 1147-1156.

39. Evans M, Park Y, Pariza M, et al. (2001) Trans-10, cis-12 conjugated linoleic reduces triglyceride content while differentially affecting peroxisome proliferator activated receptor gamma2 and aP2 expression in 3T3-L1 preadipocytes. Lipids 36, 1223-1232.

40. Peterson KF, Krssak M, Inzucchi S, et al. (2000) Mechanism of troglitazone action in type 2, diabetes. Diabetes 49, 827-831.
41. Greene DA (1999) Rosiglitazone: a new therapy for type 2 diabetes. Exp Opin Invest Drug 8, 1709-1719.

42. Boden G, Homko C, Mozzoli M, et al. (2005) Thiazolidinediones upregulate fatty acid uptake and oxidation in adipose tissue of diabetic patients. Diabetes $\mathbf{5 4}$, $880-885$.

43. Lee G, Elwood F, McNally J, et al. (2002) T007097, a selective ligand for peroxisome proliferator-activated receptor gamma, functions as an antagonist of biochemical and cellular activities. J Biol Chem 277, 19649-19657. 